\title{
PENGUATAN STRUKTUR MODAL SEBAGAI PEMENUHAN REGULASI DAN PENDUKUNG PENGEMBANGAN BISNIS
}

\author{
Tedi Setiawan \\ tedisetiawan@gmail.com \\ Jaja Suteja \\ Ellen Rusliati \\ Universitas Pasundan \\ Jl. Sumatera No.41, Bandung 40116
}

received: 28/3/2020; revised: 16/4/2020; approved: 28/4/2020

\begin{abstract}
Decision on capital structure have an important role in determinig banking performance. This study aims to find alternative strategies for Bank $X$ in fulfilling the capital requirements and to measure its the effectivities in order to reach the capital requirements of the Bank X to be in accordance with the regulations in 2018. The results of this study are expected to provide useful information related to the importance of strengthening the capital structure of the company, especially in the banking industry in order to maintain the continuity of business and to win in the market competition. The study was conducted at Bank X was located in Bandung. The research method used was survey with qualitative research approaches. While the type of research was explorative descriptive analysis. The results of the study was found three effective strategies to meet the capital needs of Bank $X$ in 2018, namely asset revaluation, reduction in dividend payout ratio (DPR) and the issuance of subordinated bonds. These three strategies could improve Capital Adequacy Ratio (CAR). while alternative simulations need to be carried out to determine the impact of the decision making.
\end{abstract}

Keywords: funds fulfillment; CAR; asset revaluation; DPR; subordinated bonds

\begin{abstract}
Abstrak
Keputusan struktur modal memiliki peran penting dalam menentukan kinerja perbankan. Penelitian ini bertujuan untuk mengetahui alternatif strategi yang dapat dilakukan Bank X dalam pemenuhan kebutuhan dana serta mengukur efektivitasnya agar rasio pendanaan sesuai dengan regulasi di tahun 2018. Hasil Penelitian diharapkan dapat memberikan informasi yang berguna terkait pentingnya memperkuat struktur modal perbankan demi menjaga keberlangsungan bisnis dan memenangkan persaingan. Penelitian dilakukan pada Bank X yang berlokasi di Kota Bandung. Metode penelitian menggunakan survey dengan pendekatan kualitatif. Analisis dilakukan dengan deskriptif eksploratif. Hasil penelitian ditemukan tiga strategi yang efektif dalam memenuhi kebutuhan modal Bank X di tahun 2018 yaitu revaluasi aset, penurunan Dividend Payout Ratio (DPR), dan penerbitan obligasi subordinasi. Ketiga strategi ini dapat meningkatkan Capital Asset Ratio (CAR). Simulasi alternatif perlu dilakukan untuk mengetahui dampak atas keputusan yang dibuat.
\end{abstract}

Kata Kunci: pemenuhan dana; CAR; revaluasi asset; DPR; obligasi subordinasi 


\section{PENDAHULUAN}

Industri perbankan merupakan sektor usaha yang secara kontinu memerlukan tambahan modal seiring dengan perkembangan volume usaha. Kecukupan permodalan selain menentukan kemampuan ekspansi usaha juga daya saing. Bank harus menyediakan permodalan sesuai risiko yang ditanggung dan mengukurnya berdasarkan risiko serta mengembangkan budaya risiko pada seluruh jajaran organisasi. Pendekatan tradisional menyatakan bahwa struktur modal mempunyai pengaruh terhadap nilai perusahaan. Hal ini mengindikasikan pentingnya memperkuat struktur modal agar perusahaan menjadi semakin bernilai. Penentuan stuktur modal akan memperkuat produktivitas bisnis lalu meningkatkan pendapatan dan keuntungan dan pada akhirnya akan meningkatkan posisi keuangan perusahaan dalam hal ini bank (Van Horne, James C; Wachowicz, John M., 2012).

Struktur modal yang baik sangat diperlukan untuk melakukan ekspansi bisnis perbankan seperti mengembangkan sistem teknologi informasi terbaru, meningkatkan kompetensi SDM, memperluas jaringan kantor, maupun meningkatkan skala usaha guna mendukung peningkatan kapasitas pertumbuhan kredit perbankan dalam rangka meningkatkan pertumbuhan ekonomi. Perbankan akan lebih leluasa dalam mengimplementasikan rencana strategis yang telah disusun apabila memiliki struktur modal yang cukup guna mencapai tujuan. Penentuan struktur modal memiliki pengaruh yang beragam terhadap kinerja keuangan sehingga perlu dilakukan secara hati-hati.

Hasil penelitian (Martis, 2013) menunjukkan bahwa struktur modal berpengaruh negatif dan signifikan terhadap kinerja bank, sehingga diperlukan komposisi yang optimum antara hutang dengan modal sendiri. Demikian pula (Siddik, et al., 2017) yang melakukan penelitian di Bangladesh, karena pasar obligasi dan saham belum berkembang, seperti informasi yang tidak simetris, perjanjian hutang yang terlalu ketat, biaya hutang yang terlalu tinggi. Hasil penelitian ini menyarankan penggunaan dana dari laba ditahan dalam pemenuhan kebutuhan dananya. Penelitian (Gohar et al., 2016) di Pakistan menunjukkan hasil yang sama. Sedangkan (Widyastuti et al., 2019) menunjukkan struktur modal tidak berpengaruh signifikan terhadap kinerja perbankan. Selanjutnya (Moshin Hafeez et al., 2018) menunjukkan struktur modal berpengaruh positif terhadap kinerja. Penelitian (Margaretha \& Setiyaningrum, 2011) menunjukkan bahwa rasio Equity to Total Liabilities (EQTL) berpengaruh positif terhadap CAR.

Otortitas Jasa Keuangan (OJK) telah menyatakan pentingnya kecukupan permodalan bagi industri perbankan dalam POJK Nomor 11/POJK.03/2016 Tentang Kewajiban Penyediaan Modal Minimum Bank Umum. Bank X dipilih karena merupakan bank pemerintah yang telah go public dengan pertumbuhan bisnis yang tinggi dan memiliki visi menjadi 10 bank terbesar di Indonesia sehingga membutuhkan dukungan permodalan memadai. Pada periode Maret 2016, modal inti sebesar Rp 5,9 triliun, tumbuh sebesar 4 \% dibanding Maret 2015. Rasio Kecukupan Modal (CAR) sebesar 14,93\%, turun 0,68\% dibanding periode Maret 2015. Bank X memiliki pertumbuhan bisnis yang tinggi, sehingga perlu meningkatkan struktur modal agar pengembangan bisnis dapat berjalan dengan baik. Hasil penelitian (Mutairi \& Naser, 2015), (Suhardi \& Afrizal, 2019) menunjukkan bahwa pertumbuhan berpengaruh positif dan signifikan terhadap struktur modal.

Perlambatan ekonomi domestik dan global yang terjadi tidak mempengaruhi kinerja bisnis Bank X, karena terjadi peningkatan capaian kredit dari Desember 2015 sampai Juni 2016. Pertumbuhan kredit yang tinggi akan meningkatkan laba, namun meningkatkan risiko. Pertumbuhan bisnis ini akan membutuhkan struktur modal yang lebih kuat agar dapat mereduksi risiko bisnis yang timbul.

Kebutuhan dana mempengaruhi nilai perusahaan, menurut trade-off, pecking order, dan free cash flow theory, sedangkan Modigliani-Miller mengemukakan tidak adanya pengaruh (Van Horne, James C; Wachowicz, John M., 2012), (Xhaferi \& Xhaferi, 2015). Kebutuhan permodalan dapat dipenuhi melalui beberapa alternatif. Hasil penelitian (Culata \& Gunarsih, 2012) menunjukkan bahwa perusahaan yang terdaftar di BEI menggunakan metode trade-off dalam penentuan struktur modalnya. Pecking order theory (POT) yang dikemukakan (Myers, 1984), (Brealey et al., 2016) membuat urutan preferensi dalam pemenuhan modal sebagai berikut: (1) sumber internal, (2) penyesuaian DPR, (3) cash flow atau surat berharga, (4) jika modal dari sumber eksternal diperlukan, perusahaan akan mengeluarkan surat berharga yang paling aman terlebih dulu, memulai dengan hutang, kemudian dengan surat berharga campuran seperti obligasi, dan saham sebagai pilihan terakhir.

POT mempunyai asumsi bahwa DPR selalu konstan. Sementara kenyataannya selalu berubah sesuai dengan preferensi pemegang saham dan kesepakatannya dengan manajemen. Pemenuhan modal perusahaan pun tidak selalu sesuai dengan urutan preferensi yang disusun sesuai dengan teori. Strategi pemenuhan modal akan sangat bergantung pada kondisi bisnis dan makro yang terjadi.

Penelitian ini memfokuskan pada strategi penguatan permodalan baik yang bersumber dari internal maupun eksternal karena diyakini merupakan faktor kunci yang akan membantu bank dalam memenuhi regulasi, juga meningkatkan kemampuan dalam menghadapi berbagai risiko. Indikator untuk mengukur kemampuan bank dalam mempertahankan modal, serta mengidentifikasi, mengukur, mengawasi, dan mengontrol risiko yang 
dapat berpengaruh terhadap besarnya modal adalah melalui rasio kecukupan modal (CAR). Saat ini rasio kecukupan modal yang disyaratkan oleh regulator minimal sebesar $8 \%$.

Proyeksi CAR Bank X berdasarkan rencana bisnis yang disusun pada tahun 2015 tanpa adanya penambahan modal anorganik dan perubahan DPR sampai dengan tahun 2018 adalah sebesar 16,04\%, sedangkan regulator mewajibkan setiap bank untuk membentuk tambahan modal sebagai penyangga yaitu capital conservation buffer, capital countercyclical buffer, dan capital surcharge untuk memperkuat struktur permodalan dalam rangka mendukung pengembangan bisnis bank secara sehat. Tabel 1 adalah skenario pemenuhan CAR bank berdasarkan POJK Nomor 11/POJK.03/2016 Tentang Kewajiban Penyediaan Modal Minimum Bank Umum.

Tingkat Kesehatan Bank (TKB) Bank X selama tahun 2015 -2016 berada pada TKB 2 dan TKB 3. Skenario ini menggambarkan bahwa untuk dapat mengembangkan bisnis secara sehat maka CAR minimum harus sesuai dengan regulasi pemenuhan modal. Fokus penelitian ini adalah implementasi strategi Bank X untuk pemenuhan kebutuhan permodalannya. Sebagai bank yang telah melakukan Initial Public Offering, dalam proses penambahan modal terdapat regulasi yang harus dipenuhi dalam pelaksanaannya.

Posisi modal Bank X per 31 Maret 2016 adalah sebesar Rp 6,3 triliun yang berasal dari komponen modal inti Rp 5,9 trilun dan pelengkap sebesar Rp 397,5 miliar. Mengingat terdapatnya regulasi pemenuhan modal minimum melalui POJK Nomor 11/POJK.03/2016, maka Bank X perlu meningkatkan komposisi modalnya agar sesuai dengan batas minimum modal yang ditentukan oleh regulator.

Strategi yang efektif untuk mencapai pemenuhan permodalan dapat ditentukan setelah mengetahui besar pengaruh masing-masing variabel penelitian terhadap CAR agar dapat terpenuhi sesuai dengan regulasi minimum modal di tahun 2018. Strategi yang dapat dipilih adalah melalui strategi organik atau anorganik. Pertimbangan pemilihan strategi dilihat dari tingkat risiko, efektivitas, dan besarnya kontribusi terhadap peningkatan CAR. Pemilihan strategi dapat dilakukan dengan membuat simulasi masing-masing kemungkinan serta melihat biaya dan manfaatnya.

Penguatan struktur modal akan membuat bank menjadi lebih mudah dalam melakukan ekspansi bisnis. Risiko bisnis yang timbul dapat dimitigasi lebih kuat lagi, dapat menahan gejolak ekonomi baik domestik maupun global, menjaga persaingan dengan bank lainnya, serta menjadi faktor penting dalam peningkatan kualitas layanan dan produk bank.

Proposisi penelitian dirumuskan sebagai berikut: (1) Bank X dapat memilih alternatif strategi dalam pemenuhan kebutuhan permodalannya melalui strategi organik atau anorganik. (2) Strategi pemenuhan permodalan yang dipilih harus mampu meningkatkan komposisi modal agar sesuai dengan regulasi dan kebutuhan modal Bank X di tahun 2018.

\section{METODE}

Penelitian ini menggunakan metode kualitatif dan analisis deskriptif eksploratif. Proses penelitian dilakukan untuk mengetahui dan mendeskripsikan alternatif strategi yang dapat diambil manajemen Bank $\mathrm{X}$ untuk memenuhi kebutuhan permodalannya dan seberapa besar pemenuhan permodalan yang dapat dicapai dengan strategi tersebut sehingga bank dapat terus tumbuh menjalankan bisnisnya sesuai regulasi yang berlaku.

Kebutuhan permodalan Bank X yang tercermin dalam CAR akan mempertimbangkan regulasi yang ada yaitu penambahan buffer seperti capital conservation buffer, capital countercyclical buffer, dan capital surcharge bank sistemik. Adanya regulasi tersebut membuat Bank X memiliki kewajiban tambahan untuk menambah minimum kebutuhan rasio permodalannya. Strategi pengembangan usaha Bank X dari sisi eksternal akan dipelajari melalui: (1) corporate plan yang dimiliki, karena akan mempengaruhi juga kebutuhan permodalan di masa datang, (2) besaran kebutuhan modal untuk masing-masing strategi pengembangan aset produktif memiliki bobot ATMR yang berbeda tergantung daripada besarnya risiko yang melekat, (3) kinerja Bank X, anak perusahaan, dan kualitas aset, karena akan berpengaruh baik positif maupun negatif terhadap modal yang dimiliki.

Pengumpulan data dilakukan secara komprehensif dimulai dari proses mendesain penelitian, mengumpulkan, menganalisis, dan menjabarkan data serta informasi yang diperoleh. Analisis data menggunakan teknik Miles dan Huberman yaitu reduksi data, model, dan penarikan kesimpulan. Penelitian ini menggunakan triangulasi untuk mendapatkan keabsahan data, meliputi sumber, teknik pengumpulan data, dan waktu.

\section{HASIL}

Proses analisis SWOT (Strengths, Weaknesses, Opportunities, and Threats) dimulai dengan terlebih dahulu menentukan faktor internal dan eksternal yang berpengaruh terhadap struktur modal. Selisih faktor internal adalah sebesar 0,02, sedangkan selisih faktor eksternal sebesar 0,72. Posisi Bank $\mathrm{X}$ dapat dilihat pada Gambar 1, yang menunjukkan posisi sangat baik dalam menggunkan kekuatan internalnya untuk (a) mengambil keuntungan dari kesempatan eksternal, (b) menangani kelemahan internal, (c) menghindari ancaman eksternal (David, Fred R and David, 2016). 
Tahapan revaluasi aset adalah (1) menyeleksi, menunjuk dan menyepakati kerjasama dengan Kantor Jasa Penilai Publik (KJPP), (2) melakukan penilaian (appraisal) atas seluruh objek revaluasi, (3) menyampaikan keterbukaan informasi sesuai POJK Nomor 31/POJK.04/2015, (4) menyampaikan surat izin pendahuluan sesuai PMK-191/PMK.10/2015 ke Direktorat Jenderal Pajak (DJP), (5) melakukan benchmarking dengan bank lain yang telah melakukan revaluasi, (6) melakukan proses administrasi korespondensi lainnya yang diperlukan.

Dampak positif dalam melakukan revaluasi aset adalah (1) menambah CAR, (2) membaiknya neraca dengan bertambahnya nilai aset (aktiva tetap), (2) membaiknya neraca dengan bertambahnya nilai modal (selisih revaluasi), (3) membaiknya basis data kepemilikan aset tetap (jumlah, luas, lokasi, dan nilai), (4) membaiknya Debt to Equity Ratio (DER), (5) membaiknya rating bank secara keseluruhan, (6) memanfaatkan fasilitas penurunan tarif pajak $(\mathrm{PPh})$ dari $10 \%$ menjadi $4 \%$.

Tahap pertama dalam pelaksanaan revaluasi aset adalah melakukan rekonsiliasi data aset yang menjadi obyek revaluasi. Keuntungan Bank X setelah melakukan revaluasi aset sebesar $R p$ 1,558 triliun. Keuntungan ini berasal dari realisasi revaluasi aset tetap berupa tanah mencapai 377,79\% dari NJOP. Proses revaluasi aset ini telah meningkatkan CAR menjadi $17,65 \%$ pada Juni 2016.

DPR menentukan jumlah laba yang dapat ditahan sebagai sumber pendanaan. Persentase DPR yang besar akan berdampak pada terbatasnya laba ditahan. Sesuai dengan teori struktur permodalan dari Myers yaitu Teori Pecking Order bahwa kebijakan DPR yang baik adalah yang konstan (Bhaird, 2010). Menurut Myers, dengan kebijakan DPR konstan maka perusahaan akan lebih mudah dalam melakukan perencanaan keuangan setiap tahunnya, karena DPR yang berubah setiap tahun akan menimbulkan ketidakpastian sehingga mempersulit manajemen dalam membuat perencanaan keuangan.

Melalui program transformasi BPD, OJK menghimbau agar bank daerah dapat membatasi porsi DPR maksimal sebesar $40 \%$, jika memungkinkan dapat dikurangi lagi menjadi 30\%. Himbauan OJK ini dikeluarkan agar bank daerah dapat lebih leluasa dalam melakukan ekspansi bisnis melalui tambahan pencadangan modal dari penurunan DPR. Bank X merupakan bank daerah yang menjadi salah satu sumber pendapatan asli daerah, maka kebijakan DPR harus senantiasa disesuaikan dengan kebutuhan keuangan daerah.

Regulasi right issue/Hak Memesan Efek Terlebih Dahulu (HMETD) tercantum dalam Peraturan Bapepam LK No. IBJB D.1 Tentang Penambahan Modal dengan Hak Memesan Efek Terlebih Dahulu, yaitu: (a) HMETD adalah hak yang melekat pada saham yang memungkinkan para pemegang saham yang ada untuk membeli saham baru sebelum ditawarkan kepada pihak lain, (b) apabila suatu perusahaan bermaksud untuk menambah modal sahamnya, maka setiap pemegang saham wajib diberi HMETD atas saham baru dimaksud sebanding dengan persentase pemilikan, (c) jika suatu perusahaan sebagaimana dimaksud pada angka 2 mempunyai lebih dari satu jenis saham dan jika jumlah saham dalam setiap jenis ditambah secara proporsional, maka para pemegang saham yang ada wajib mempunyai HMETD sebanding dengan persentase pemilikan dalam masing-masing jenis saham, (d) jika suatu perusahaan sebagaimana dimaksud pada angka 2 mempunyai lebih dan satu jenis saham tetapi penambahan hanya terjadi pada satu jenis saham saja, atau jumlah penambahan dari setiap jenis saham tidak sebanding, maka semua pemegang saham wajib mempunyai HMETD sebanding dengan persentase pemilikan.

Penambahan Modal Tanpa (PMT) HMETD adalah mekanisme penyertaan modal pada perusahaan terbuka melalui penawaran pembelian saham baru kepada pemegang saham eksisting maupun baru tanpa memperhitungkan komposisi kepemilikan sahamnya dengan mengikuti tata cara dan ketentuan yang berlaku di pasar modal. Regulasi mengenai PMT HMETD tercantum pada POJK No. 38/POJK.04/2014 tentang Penambahan Modal Tanpa Hak Memesan Efek Terlebih Dahulu pada Bab II pasal 2 ayat 1-3.

Berdasarkan perbandingan tersebut, maka untuk memenuhi kebutuhan modal, Bank X lebih baik menggunakan mekanisme PMT HMETD dengan pertimbangan antara lain sebagai berikut: (1) adanya keleluasaan waktu selama 2 tahun sejak RUPS bagi pemda untuk melaksanakan penyertaan modal, (2) terdapat beberapa pemda yang belum memiliki saham Bank X dan akan menjadi pemegang saham sehingga akan lebih dimungkinkan diberikan saham Seri A yang khusus dimiliki pemerintah, (3) dalam kondisi terjadi kemungkinan adanya pemda yang tidak dapat melakukan penyertaan modal, pemda lain dapat menjadi pembeli siaga, (4) mengingat dalam mekanisme PMT HMETD jumlah saham yang dapat ditawarkan maksimal sebanyak 10\%, maka untuk menambah kebutuhan modal tambahan selain bersumber dari penerbitan saham baru, penambahan modal dapat juga bersumber dari peningkatan cadangan melalui penurunan DPR.

Beberapa hal yang perlu diperhatikan sebelum Bank X memutuskan untuk melakukan PMT HMETD yaitu adanya regulasi yang belum jelas terkait penyertaan modal sebagai berikut: (i) Pasal 41 Ayat 5 UU Nomor 1/2004 tentang Perbendaharaan Negara: "penyertaan modal Pemerintah Daerah pada perusahaan negara/daerah/swasta ditetapkan dengan PERATURAN DAERAH", (ii) Pasal 75 PP Nomor 58/2005 tentang Pengelolaan Keuangan 
Daerah: "penyertaan modal pemerintah daerah dapat dilaksanakan apabila jumlah yang akan disertakan dalam tahun anggaran berkenaan telah ditetapkan dalam peraturan daerah tentang penyertaan modal daerah berkenaan", (iii) Surat dari Kemendagri nomor 900/4622/SJ tanggal 21 Desember 2009 perihal Penjelasan Pasal 71 ayat 7 Permendagri Nomor 13 Tahun 2006 tentang Pedoman Pengelolaan Keuangan Daerah: "Pemerintah daerah dapat melakukan investasi yang diantaranya adalah dalam bentuk penyertaan modal dengan beberapa alasan, antara lain memanfaatkan surplus anggaran untuk memperoleh sejumlah pendapatan dalam jangka panjang yakni dalam bentuk hasil pengelolaan kekayaan daerah yang dipisahkan seperti dividen", (iv) belum jelasnya perlakuan akuntansi atas transaksi penyetoran modal pemerintah daerah pada perusahaan terbuka, (v) kemungkinan terjadinya perbedaan harga saham antara harga asumsi, harga keputusan RUPS dan harga pada saat pelaksanaan penyertaan modal.

Obligasi subordinasi sebagaimana diatur antara lain dalam Peraturan Otoritas Jasa Keuangan Nomor 11/POJK.03/2016 tentang Kewajiban Penyediaan Modal Minimum Bank Umum. Pengaturan obligasi subordinasi dalam POJK Nomor 11/POJK.03/2016 adalah dalam konteks obligasi subordinasi sebagai salah satu komponen modal bank dan termasuk dalam kategori modal pelengkap level bawah (lower tier 2). Secara garis besar, perbedaan antara obligasi biasa dan obligasi subordinasi adalah: (1) obligasi biasa tidak dapat masuk ke dalam komponen modal, obligasi subordinasi dapat masuk ke dalam komponen modal (kategori modal pelengkap) maksimal sebesar $50 \%$, (2) obligasi biasa dapat memiliki opsi buyback sebelum jatuh tempo, obligasi subordinasi tidak membolehkan adanya opsi buyback. Pelunasan kembali obligasi subordinasi harus atas persetujuan dari Otoritas Jasa Keuangan (OJK), (3) pembayaran yield obligasi subordinasi dapat ditangguhkan apabila kondisi dari struktur modal bank dirasa tidak baik. Pembayaran yield dapat diakumulasikan dengan periode sebelumnya, (4) obligasi subordinasi dapat dikonversi menjadi saham biasa apabila bank tidak dapat membayar atau melunasi obligasi subordinasi yang sudah diterbitkan setelah mendapat persetujuan dari OJK. Konversi obligasi subordinasi menjadi saham akan membuat pos komponen modal pelengkap dari obligasi subordinasi berpindah ke pos modal inti sebesar nilai konversi.

Tahapan pelaksanaan, persyaratan, dan penawaran atas penerbitan obligasi subordinasi sama seperti penerbitan obligasi biasa. Obligasi subordinasi merupakan surat utang junior yang disubordinasi terhadap utang senior. Obligasi subordinasi (An, et al., 2015) tidak saja untuk menurunkan risiko, namun juga meningkatkan posisi kredit penerbit. Obligasi subordinasi ini dapat dijadikan alternatif Bank X dalam memenuhi kebutuhan modal. Beberapa Bank menerbitkan obligasi subordinasi ketika rasio CAR menurun dan berusaha untuk meningkatkan CAR agar tetap terjaga di atas batas minimum regulasi yang berlaku.

\section{PEMBAHASAN}

Posisi Bank X berada pada kuadran I, berarti kondisi yang mendukung dalam meningkatkan modal baik melalui strategi secara organik maupun anorganik. Strategi organik melalui revaluasi aset dan DPR serta strategi anorganik melalui HMETD, PMT HMETD, dan obligasi subordinasi. Sebelum menentukan alternatif strategi mana yang efektif bagi Bank X dalam memenuhi kebutuhan modal di tahun 2018, perlu dilakukan evaluasi terhadap masing-masing strategi baik organik maupun anorganik untuk selanjutnya ditentukan strategi mana yang dirasa paling baik untuk dilakukan oleh Bank X. Tabel 2 adalah hasil evaluasi dari masingmasing alternatif strategi pemenuhan modal yang dapat dilakukan oleh Bank X.

Strategi yang dapat dilakukan Bank X untuk memenuhi kebutuhan CAR minimum di 2018 yaitu melalui revaluasi aset, penyesuaian DPR, dan penerbitan obligasi subordinasi. Ketiga strategi ini perlu dilakukan bersamaan agar kebutuhan modal di tahun 2018 dapat terpenuhi. Revaluasi harus dilakukan sesuai dengan keterntuan pemerintah dan situasi pasar, sehingga memberikan informasi yang lebih tepat sesuai dengan kondisi saat ini. Revaluasi aset sudah dilaksanakan di tahun 2016 dan telah menambah CAR Bank X sebesar 2,72\%. Hasil ini mendukung penelitian (Suhardi \& Afrizal, 2019) bahwa aktiva berwujud berpengaruh terhadap struktur modal.

Hasil penelitian (Baker \& Weigand, 2015) menunjukkan bahwa kebijakan dividen sangat penting, karena melibatkan jumlah yang banyak, dan menjadi perhatian perusahaan, analis, dan pemegang saham. Kebijakan dividen dipengaruhi oleh tingkat keuntungan, peningkatan keuntungan, ukuran direksi, kebebasan direksi, leverage, dan jenis audit (Nuhu, 2014). DPR diasumsikan turun $10 \%$ per tahun sampai dengan tahun buku 2017 dengan simulasi berikut: (a) Pada tahun 2017 asumsi DPR sebesar 50\%-50\% dari laba tahun buku 2016 dan ada tambahan modal dari obligasi subordinasi sebesar Rp 850 miliar dengan nilai penerbitan obligasi sebesar Rp 1,7 triliun karena yang dapat masuk ke dalam modal pelengkap hanya sebesar $50 \%$ dari nilai obligasi.

Pada tahun 2018 asumsi DPR sebesar 40\% dari laba tahun buku 2017 dan ada tambahan modal dari obligasi subordinasi sebesar Rp 850 miliar dari nilai obligasi Rp 1,7 triliun. Dampak terhadap CAR melalui ketiga alternatif strategi dapat dilihat dari Tabel 3. Kombinasi tiga alternatif strategi pemenuhan modal (revaluasi, DPR, dan obligasi subordinasi) Bank X 
berdampak sebagai berikut: (1) CAR tahun 2016 sebesar $17,63 \%$ terbantu dari hasil revaluasi aset yang telah dilakukan pada bulan Juni 2016. (2) Tahun 2017 CAR menjadi $17,78 \%$ dengan adanya tambahan modal dari cadangan yang berasal dari DPR yang diturunkan menjadi 50\% dari proyeksi laba tahun 2016 ditambah adanya tambahan modal dari obligasi subordinasi sebesar Rp 850 miliar. Nilai dari obligasi subordinasi ini akan terus muncul dalam KPMM Bank X sampai waktu jatuh tempo. Tambahan modal dari obligasi subordinasi ini tidak terlalu berdampak signifikan pada peningkatan CAR karena di tahun 2017 Bank X berencana untuk memberikan suntikan modal ke anak perusahaan sebesar Rp 435 miliar. Hal ini membuat sebagian tambahan modal dari obligasi subordinasi terserap oleh suntikan modal ke anak perusahaan, (3) CAR tahun 2018 menjadi 18,53\% yang diperoleh dari DPR 40\% dari proyeksi laba tahun 2017 ditambah adanya tambahan modal kembali sebesar Rp 850 miliar dari obligasi subordinasi. Namun tidak menutup kemungkinan bahwa tambahan modal ini dapat juga berasal dari proses PMT HMETD, apabila di tahun 2018 regulasi sudah jelas dan kondisi mendukung untuk dilakukannya PMT HMETD.

Pemenuhan kebutuhan dana yang dilakukan Bank X mengacu pada POT (Myers, 1984), bahwa sumber internal memiliki rangking tertinggi, karena jumlahnya tidak mencukupi maka ditambah obligasi subordinasi. Penerapan POT memungkinkan Bank menekan risiko dan tetap dapat memenuhi regulasi yang ditetapkan. Manajer dan investor senantiasa memperhatikan setiap aktivitas bank untuk mencapai kinerja terbaik (Mostafa et al., 2011). Hasil penelitian ini bertentangan dengan (Culata \& Gunarsih, 2012), karena tujuan dari pendanaan adalah pemenuhan CAR yang memenuhi regulasi. Penelitian ini mendukung hasil penelitian (Margaretha \& Setiyaningrum, 2011) bahwa peningkatan EQTL meningkatkan CAR.

\section{KESIMPULAN}

Implementasi strategi Bank X untuk memenuhi kebutuhan permodalan sesuai regulasi di tahun 2018: (1) revaluasi aset tetap dilakukan pada bulan Juni 2016 telah meningkatkan nilai CAR, (2) obligasi subordinasi tahun 2017 dan 2018 yang dapat diperhitungkan ke dalam komponen modal pelengkap dari nilai penerbitan obligasi serta penurunan DPR yang dapat meningkatkan retained earning dan selanjutnya meningkatkan CAR, (3) kombinasi alternatif strategi pemenuhan modal berupa revaluasi, DPR, dan obligasi subordinasi dapat mencukupi target kebutuhan modal minimum Bank $\mathrm{X}$ di tahun 2018. Pemenuhan kebutuhan dana jangka panjang memerlukan pertimbangan yang komprehensif melalui simulasi sehingga tetap memenuhi regulasi yang ditetapkan.

\section{DAFTAR PUSTAKA}

An, X., Deng, Y., Nichols, J. B., \& Sanders, A. B. 2015. What is Subordination About? Credit Risk and Subordination Levels in Commercial Mortgagebacked Securities (CMBS). Journal of Real Estate Finance and Economics, 51(2), 231-253. https:// doi.org/10.1007/s11146-014-9480-1

Baker, H. K., \& Weigand, R. 2015. Corporate Dividend Policy Revisited. Managerial Finance, 41(2), 126144. https://doi.org/10.1108/MF-03-2014-0077

Brealey, R. A., Myers, S. C., \& Allen, F. .2016. Principles of Corporate Finance (12th ed). McGraw-Hill Education.

Culata, P. R. E., \& Gunarsih, T. 2012. Pecking Order Theory and Trade-off Theory of Capital Structure: Evidence from Indonesian Stock Exchange. Journal The WINNERS, 13(1), 40-49.

David, Fred R and David, F. R. 2016. Manajemen Strategik. Suatu Pendekatan Keunggulan Bersaing. di alih-bahasakan oleh Novita Puspasari dan Liza Nurbani Purbasari. Edisi 15. Salemba Empat.

Gohar, M., Waseem, M., \& Rehman, U. 2016. Impact of Capital Structure on Banks Performance: Empirical Evidence from Pakistan. 7(1), 32-38.

Hafeez, M.M., Khan, H.H., Majeed, F. and Azeem, A., 2018. Impact of Capital Structure on Islamic Banks Performance: (Evidence from Asian country). Global Journal of Management And Business Research.

Margaretha, F., \& Setiyaningrum, D. 2011. Pengaruh Resiko, Kualitas Manajemen, Ukuran dan Likuiditas Bank terhadap Capital Adequacy Ratio Bank-Bank yang Terdaftar di Bursa Efek Indonesia. Jurnal Akuntansi dan Keuangan, 13(1), 47-55. https:// doi.org/10.9744/jak.13.1.47-56

Martis, R. N. 2013. Capital Structure and Financial Performance. March 2018, 1-50.

Mostafa, W., Eldomiaty, T., \& Abdou, H. 2011. The Effect of Bank Capital Structure and Financial Indicators on CI's Financial Strength Ratings: The Case of the Middle East. Banks and Bank Systems, 6(3), 5-15.

Mutairi, A. AL, \& Naser, K. 2015. Determinants of Capital Structure of Banking Sector in GCC: An Empirical Investigation. Asian Economic and Financial Review, 5(7), 959-972. https://doi. org/10.18488/journal.aefr/2015.5.7/102.7.959.972

Myers, S. C. 1984. The Capital Structur Puzzle. The Journal of Finance, XXXIX(3).

Nuhu, E. 2014. Revisiting the Determinants of Dividend Payout Ratios in Ghana. International Journal of Business and Social Science, 5(8), 230-238.

Siddik, M., Kabiraj, S., \& Joghee, S. 2017. Impacts of Capital Structure on Performance of Banks in a Developing Economy: Evidence from Bangladesh. International Journal of Financial Studies, 5(2), 13. https://doi.org/10.3390/ijfs5020013 
Suhardi, S., \& Afrizal, A. 2019. How Does the PeckingOrder Theory Explain the Bank's Capital Structure in Indonesia? MPRA Paper, 93963. https://mpra. ub.uni-muenchen.de/93963/

Van Horne, James C; Wachowicz, John M., J. alih bahasa Q. M. 2012. Prinsip-prinsip Manajemen Keuangan (13. Buku I). Salemba Empat.
Widyastuti, A., Komara, R., \& Layyinaturrobaniyah, L. 2019. Capital Structure and Bank Performance. Jurnal Bisnis dan Manajemen, 20(2), 136-144. https://doi.org/10.24198/jbm.v20i2.300

Xhaferi, S., \& Xhaferi, B. 2015. Alternative Theories of Capital Structure. European Scientific Journal, 11(7), 327-343.

Tabel 1. Skenario Pemenuhan CAR Bank X di Tahun 2018

\begin{tabular}{ccccccc}
\hline TKB & Minimum CAR & Capital Coservation Buffer & Counter Cyclical Buffer & D-SIB & CAR Minimum & CAR Required \\
\hline 1 & $8 \%$ & $2,5 \%$ & $0 \%-2,5 \%$ & $1 \%-2,5 \%$ & $11,5 \%$ & $15,5 \%$ \\
2 & $9 \%-10 \%$ & & & $12,5 \%$ & $17,5 \%$ \\
3 & $10 \%-11 \%$ & & & $13,5 \%$ & $18,5 \%$ \\
4 & $11 \%-14 \%$ & & & $14,5 \%$ & $21,5 \%$ \\
\hline
\end{tabular}

Tabel 2. Evaluasi Pilihan Alternatif Strategi Pemenuhan Modal

\begin{tabular}{|c|c|c|c|c|}
\hline \multicolumn{2}{|c|}{ Alternatif Strategi } & Kelebihan & Kekurangan & \multirow{2}{*}{$\begin{array}{c}\text { Peringkat } \\
\text { Prioritas }\end{array}$} \\
\hline Organik & Revaluasi & a. Risiko kecil & a. Hanya dapat dilakukan paling cepat 5 tahun sekali & \\
\hline & Aset & b. Proses pelaksanaan cepat & & \\
\hline & & c. Peningkatan CAR relatif besar & & \\
\hline & & d. Biaya yang dikeluarkan tidak besar & & \\
\hline & DPR & $\begin{array}{l}\text { a. Meningkatkan modal sekaligus dapat } \\
\text { digunakan untuk ekspansi bisnis }\end{array}$ & $\begin{array}{l}\text { a. Ketentuan rasio dividend payout tergantung } \\
\text { kesepakatan pemegang saham dan Bank }\end{array}$ & 2 \\
\hline & & b. Proses cepat & & \\
\hline & & c. Tidak ada biaya pelaksanaan & & \\
\hline \multirow[t]{10}{*}{ Anorganik } & HMETD & $\begin{array}{l}\text { a. Penerbitan saham dapat terserap } \\
\text { lebih cepat karena dapat dimiliki oleh } \\
\text { masyarakat umum }\end{array}$ & $\begin{array}{l}\text { a. Proses pelaksanaan relatif lebih lama karena } \\
\text { dibutuhkan sosialisasi kepada para pemegang } \\
\text { saham. }\end{array}$ & 3 \\
\hline & & $\begin{array}{l}\text { b. Saham yang dapat diterbitkan lebih } \\
\text { banyak dari mekanisme PMT }\end{array}$ & $\begin{array}{l}\text { b. Akan terjadi dilusi terhadap suara dari pemegang } \\
\text { saham Pemda }\end{array}$ & \\
\hline & & & c. Penentuan harga tergantung keputusan RUPS & \\
\hline & $\begin{array}{c}\text { PMT } \\
\text { HMETD }\end{array}$ & $\begin{array}{l}\text { a. Suara pemegang saham Pemda (Seri A) } \\
\text { dapat terjaga }\end{array}$ & a. Dibutuhkan sosialisasi kepada pemegang saham & 4 \\
\hline & & $\begin{array}{l}\text { b. Adanya keleluasaan proses penyetoran } \\
\text { modal yaitu selama } 2 \text { tahun sejak RUPS. }\end{array}$ & $\begin{array}{l}\text { b. Saham yang dapat diterbitkan maksimal } 10 \% \\
\text { dari total saham yang beredar }\end{array}$ & \\
\hline & & $\begin{array}{r}\text { c. Penentuan harga jelas yaitu dari rata-rata } \\
\text { harga saham } 25 \text { hari bursa sebelum RUPS }\end{array}$ & $\begin{array}{l}\text { c. Belum adanya regulasi yang jelas terkait } \\
\text { perlakukan akuntansi atas transaksi setoran modal } \\
\text { Pemda kepada PT. }\end{array}$ & \\
\hline & $\begin{array}{l}\text { Obligasi } \\
\text { Subordinasi }\end{array}$ & $\begin{array}{l}\text { a. Dapat diperhitungkan ke dalam komponen } \\
\text { modal pelengkap sebesar } 50 \%\end{array}$ & a. Tidak adanya opsi buyback & 5 \\
\hline & & b. Pembayaran yield dapat ditangguhkan & b. Memiliki risiko yang relatif besar karena menjadi & \\
\hline & & c. Dapat dikonversi menjadi saham biasa & beban Bank & \\
\hline & & d. Jatuh tempo maskimal 10 tahun & & \\
\hline
\end{tabular}




\begin{tabular}{|c|c|c|c|}
\hline & Revaluasi & $\begin{aligned} & \text { DPR } 50 / 50 \\
+ & \text { subdebt } 850 \mathrm{M}\end{aligned}$ & $\begin{array}{l}\text { DPR } 40 / 60+ \\
\text { subdebt } 850 \mathrm{M}\end{array}$ \\
\hline \multirow[t]{2}{*}{ URAIAN } & \multicolumn{3}{|c|}{ Tahun (Rp juta) } \\
\hline & 2016 & 2017 & 2018 \\
\hline \multicolumn{4}{|l|}{ KOMPONEN MODAL } \\
\hline I. Modal Inti & 8.121 .650 & 8.249 .000 & 9.396 .741 \\
\hline Modal Inti Utama (CET I) & 8.121 .650 & 8.249 .000 & 9.396 .741 \\
\hline Modal Inti Tambahan (AT-1) & - & - & - \\
\hline II. Modal Pelengkap & 490.351 & 1.395 .954 & 2.345 .116 \\
\hline $\begin{array}{l}\text { Instrumen modal dalam bentuk saham atau lainnya yang } \\
\text { memenuhi persyaratan }\end{array}$ & - & 850.000 & 1.700 .000 \\
\hline Agio/Disagio yang berasal dari penerbitan instrumen pelengkap & - & - & - \\
\hline $\begin{array}{l}\text { Cadangan umum aset produktif PPA yang wajib dibentuk (maks. } \\
1,25 \% \text { ATMR Risiko Kredit) }\end{array}$ & 490.351 & 545.954 & 645.116 \\
\hline Cadangan tujuan & - & - & - \\
\hline Faktor Pengurang Modal Pelengkap & - & - & - \\
\hline Total Modal & 8.612 .000 & 9.644 .954 & 11.741 .857 \\
\hline \multicolumn{4}{|l|}{ ASET TERTIMBANG MENURUT RISIKO } \\
\hline ATMR Risiko Kredit & 39.228 .049 & 43.622 .660 & 51.609 .305 \\
\hline ATMR Risiko Pasar & 475.410 & 528.481 & 692.151 \\
\hline ATMR Risiko Operasional & 9.156 .804 & 10.106 .804 & 11.081 .804 \\
\hline Total ATMR & 48.860 .264 & 54.257 .945 & 63.383 .259 \\
\hline \multicolumn{4}{|l|}{ Rasio KPMM } \\
\hline Rasio CET 1 & $16.62 \%$ & $15,20 \%$ & $14,83 \%$ \\
\hline Rasio Tier 1 & $16,62 \%$ & $15,20 \%$ & $14,83 \%$ \\
\hline Rasio Tier 2 & $1 \%$ & $2,57 \%$ & $3,70 \%$ \\
\hline Rasio Total & $17,63 \%$ & $17,78 \%$ & $18,53 \%$ \\
\hline
\end{tabular}




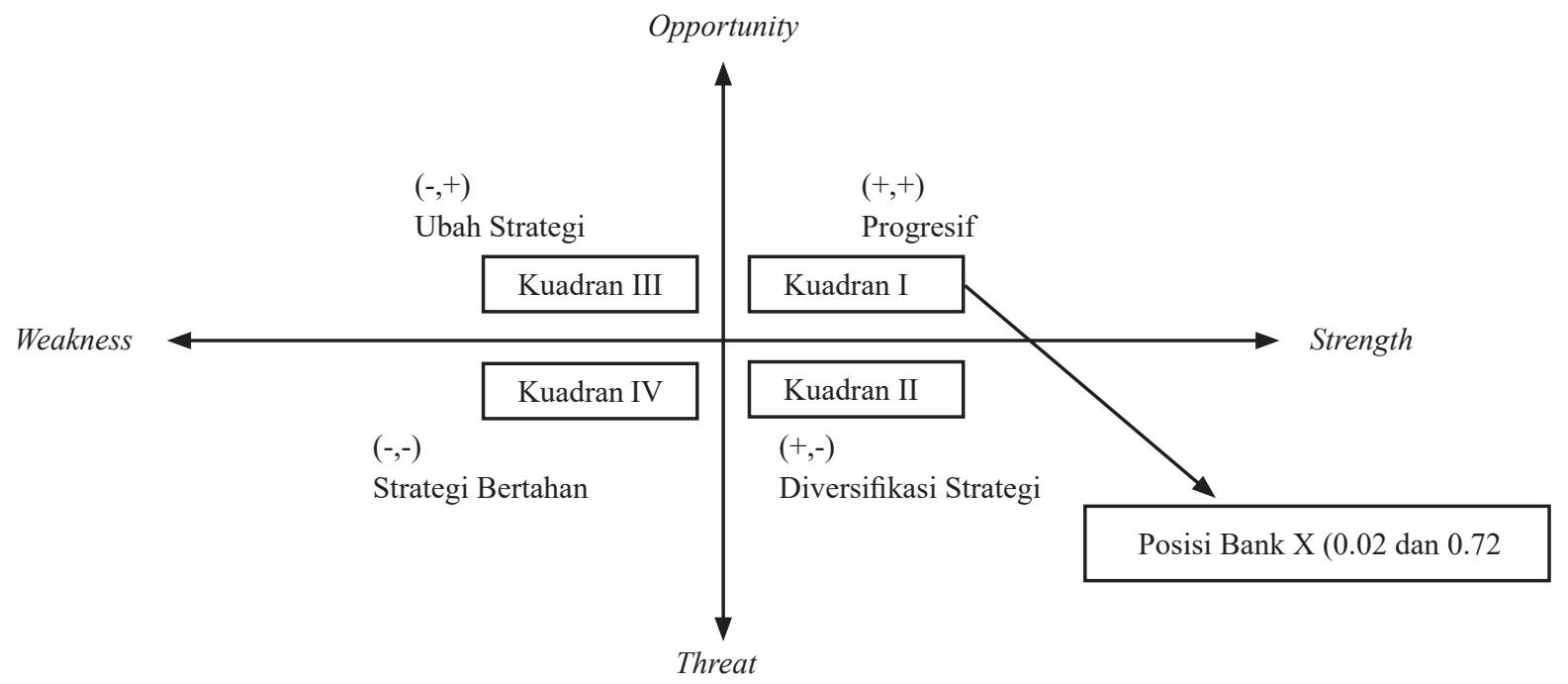

Gambar 1. Analisis SWOT Pemenuhan Modal Bank X 